\title{
Ethmoidal Artery
}

National Cancer Institute

\section{Source}

National Cancer Institute. Ethmoidal Artery. NCI Thesaurus. Code C52855.

One of two vessels (anterior or posterior) carrying oxyg enated blood to areas in the cranium, sinuses and nasal regions. 